\title{
A brief taxonomic history of neotropical mistletoe genera, with a key to the genera
}

\author{
J. Kuijt ${ }^{1}$
}

Key words

generic history

mistletoes

Neotropics

\begin{abstract}
A brief chronological account is provided of the discovery and recognition of the genera of the New World mistletoes, with a key to the genera.
\end{abstract}

Published on 11 December 2013
When European botanists were first faced with mistletoes of the New World they interpreted them, not surprisingly, within the framework of the mistletoes they knew from their own continent. The new discoveries were thus initially placed in either Loranthus Jacq. or Viscum L. It was to be a long time before it was realized that neither of these genera occur in the New World, and that a fresh look was needed; even Bentham (1880), for example, continued to place all Loranthaceae (in the modern sense) in Loranthus, with the singular exception of the extraordinary Australian genus Nuytsia R.Br.

The first New World mistletoe recognized (and illustrated) as a new species seems to have been Tristerix corymbosus (L.) Kuijt, under the designation Periclymenum foliis acutis floribus profunde dissectis .... (Feuillée 1714; see Kuijt 1988b: 20-21). Linnaeus later (1753) renamed this plant Lonicera corymbosa L., from which the present, acceptable binomial is derived.

The primarily northern hemisphere genus Arceuthobium M. Bieb. was the earliest American genus to receive a separate name (as Razoumofskya Hoffmann, 1808, later named Arceuthobium M.Bieb. (Marschall von Bieberstein 1819), even though it was not then recognized that the genus also occurred in the New World - especially that most diversity in the genus existed there; the earliest known New World species was at first placed in Viscum (V. vaginatum Willd., Willdenow 1806).

No exclusively American genus was recognized until 1830 (Martius 1830), and the rapid subsequent developments can at least in part be credited to the Brazilian travels of this author (1817-1820) and the collections he brought back to Germany. The generic names published by him in that year (Phthirusa Mart., Psittacanthus Mart., Struthanthus Mart. and Tristerix Mart.) remain accepted today. Tristerix included some Old World species. Even before Martius had broken through this mental logjam, other generic names that survive today had begun to appear (Gaiadendron G.Don and Notanthera (DC.) G.Don, Don 1834; Antidaphne Poepp. \& Endl., Poeppig \& Endlicher 1838; Dendropemon (Blume) Rchb., Reichenbach 1841; Eubrachion Hook.f. and Lepidoceras Hook.f. (Hooker 1846); Passovia H.Karst., Karsten 1846; and Phoradendron Nutt., Nuttall 1848). Passovia was published in a fashion that today would be unacceptable. The curious genus Misodendrum Banks ex DC. was first described as part of Loranthaceae (De Candolle 1830)

\footnotetext{
649 Lost Lake Road, Victoria B.C. V9B 6E3, Canada;

e-mail: jkuijt@uvic.ca.
}

and later placed in Santalaceae by Bentham (1880), but was earlier recognized as representing a distinct American family (Agard 1858).

No additional American genera appeared in print until 1868, when Eichler published his monumental account of Brazilian mistletoes, an account that also contained much information concerning other neotropical countries. It is difficult not to have the greatest admiration for Eichler's contribution, especially since it was the only contribution to mistletoe taxonomy he published; a century and a half later, it is still necessary to consult its contents in our work. Eichler was a disciple of Martius and, having full access to Martius' collections, he brilliantly consolidated the latter's generic concepts. However, he went considerably further than his mentor by producing the genera Ixidium Eichler, Oryctanthus Eichler and Dendrophthora Eichler, Ixidium presently being placed under synonymy in Antidaphne (Kuijt 1988a). The latter genus was known to him but, in an inconspicuous footnote on p. 96 (not 98, as stated erroneously in Kuijt 1988a), its treatment was referred to Santalaceae where the genus was subsequently overlooked. His judgment (even though he placed the other Brazilian Eremolepidaceae in subfamily Visceae) is intriguing in the light of modern molecular studies indicating close affinities of Eremolepidaceae with, or even incorporation within, Santalaceae (Nickrent et al. 2010). Eichler also introduced Psittacanthus subg. Aetanthus Eichler, recognized as a distinct genus since Engler (1889).

Eichler nevertheless made two serious errors that have bedevilled mistletoe systematics subsequently. The first of these was the erection of his new genus Phrygilanthus Eichler that was said to have species both in the New and the Old World. After a century of confusion, this situation was fortunately clarified by Barlow \& Wiens (1973), where Eichler's neotropical species are referred to Desmaria, Gaiadendron, Notanthera, Tripodanthus and Tristerix. Eichler's remaining Phrygilanthus species - all Australian - are presently placed in Muellerina (Barlow 1997), rendering the generic name superfluous. The second, more inconspicuous error has persisted until our day, and requires a brief, separate discussion.

Phthirusa in the sense of Martius consisted of a single, relatively rare species, Phthirusa clandestina (Mart.) Mart. from Atlantic Brazil. It has sessile flowers without inflorescences and other features that later suggested even to Bentham (1880) affinities to his Mexican Loranthus inconspicuus Benth. Eichler fundamentally altered the circumscription of Phthirusa by including (or 
newly describing) many species with inflorescences and other features that clash with $P$. clandestina. The weight of Eichler's authority was such that his arrangement was not questioned until Kuijt (2011), where I returned to Martius' original conception, relegating other species to Passovia, the only other generic name available. Six other species were at that time recruited from Ixocactus Rizzini into Phthirusa, including the above "Loranthus inconspicuus".

Following Eichler's publication, no new neotropical Loranthaceous genera were published until 1895. It was then that the French botanist Van Tieghem produced a sudden burst of generic names that, with a couple of exceptions, can now be seen as a mostly meaningless proliferations of the taxonomic literature. The most striking instance was when he introduced, usually with very scant information (and, as always, without any illustrations), a large number of new genera within what are now considered Aetanthus, Psittacanthus and Struthanthus, as well as some beyond these genera (Van Tieghem 1895a, b). This nomenclatural grapeshot did, however, produce some small genera that remain currently recognized (Desmaria Tiegh., Ligaria Tiegh., Oryctina Tiegh. and Tripodanthus Tiegh.) as well as two others that he based on a single species each but that have more recently been enlarged significantly (Cladocolea Tiegh. and Peristethium Tiegh.; Kuijt 1975, 2012). In the second edition of Die Natürlichen Pflanzenfamilien (Engler \& Krause 1935) and earlier in Engler (1897), Van Tieghem's genera were taken seriously but simply reduced to subgeneric rank without any analytical comments (Desmaria and Peristethium remaining at the generic level). Across the Channel, the Eurocentric view of Loranthaceae persisted (Bentham1880), the worldwide genus Loranthus having become progressively more complex and unwieldy.

Since Van Tieghem's time, a few more, very small genera were published intermittently for the New World. Psathyranthus Ule (Ule 1906-1907) later turned out to be one of several unusual Amazonian species of Psittacanthus (Kuijt 1983, 2009). Ixocactus (Rizzini 1952) can now be seen to be part of an enlarged Phthirusa in Martius' sense (Kuijt 2011), while Furarium Rizz. (Rizzini 1956) is - perhaps questionably - placed in Passovia. Panamanthus Kuijt (Kuijt 1991) and Pusillanthus Kuijt (Kuijt 2008) are monotypic genera that will probably continue to be accepted, as will Maracanthus Kuijt (Kuijt 1976). However, the genus Passovia as now circumscribed is known to have a baffling amount of anther diversity that cannot preclude further segregates (Kuijt 2011). Elsewhere, a single and extremely rare Mexican species of Cladocolea, C. biflora Kuijt, has such an extraordinary floral structure that it might be a fair candidate for generic segregation if more adequate material were available (Kuijt 1980).

With regard to the neotropical genera beyond Loranthaceae, little needs to be reported: generic synonyms are listed for Eremolepidaceae in Kuijt (1988a), for Viscaceae in Kuijt (1961, Dendrophthora) and Kuijt (2003, Phoradendron), for Arceuthobium in Hawksworth \& Wiens (1996) and for Misodendraceae in Orfila (1978). However, some comments on the admittedly difficult distinction between Dendrophthora and Phoradendron seem appropriate (see the discussion in Kuijt 2003: 34), as it has been argued that both genera are paraphyletic (Nickrent et al. 2010). Fortunately, no one has seriously proposed to unite these two very large genera (together having more than 350 species), of which only a minute fraction of each has been included in the molecular work on which these conclusions are based. In at least one case (Ashworth 2000a, b, Nickrent et al. 2010), an important argument turned out to reflect a gap in knowledge. Dendrophthora guatemalensis Standl., when investigated by Ashworth (2000a) showed clearly that it has a genetic makeup linked to Phoradendron. At that time the male flowers of the species were not yet known. When they were later found and analysed, it was discovered that the anthers are bilocular; the species had thus been misplaced in Dendrophthora to begin with, and this argument for paraphyly of the genus automatically became moot. The species is now known as Phoradendron naviculare Kuijt (Kuijt 2003). Nevertheless, it appears that Dendrophthora occupies a nested position in Phoradendron, but taking the uncertainties linked to limited sampling and difficult identifications in this group into account, I do not consider this necessarily requiring nomenclatural action yet.

A revised classification of the Order Santalales has recently restructured the relationships of the mistletoe families among each other and with other parasitic or autotrophic members of the order (Nickrent et al. 2010). The newly proposed or reintroduced taxa for the Loranthaceae of the New World include tribe Psittacantheae Horan subtribe Psittacanthinae Engl. (all small-flowered genera, including Tripodanthus, as well as Aetanthus and Psittacanthus), subtribe Notantherinae Nickrent \& Vidal-Russ. (Desmaria \& Notanthera) and subtribe Ligarinae Nickrent \& Vidal-Russ. (Ligaria \& Tristerix).

Finally, it should be mentioned that APG III (2009) placed Viscaceae in Santalaceae, a move now followed in some publications but not by Nickrent et al. 2010 or myself.

\section{Estimated species numbers in neotropical genera}

$\begin{array}{lrlr}\text { Aetanthus } & 12 \text { or } 13 & \text { Notanthera } & 1 \\ \text { Antidaphne } & 9 & \text { Oryctanthus } & 15 \\ \text { Arceuthobium } & 18 & \text { Oryctina } & 6 \\ \text { Cladocolea } & 28 & \text { Panamanthus } & 1 \\ \text { Dendropemon } & 32+ & \text { Passovia } & 22+ \\ \text { Dendrophthora } & 115 & \text { Peristethium } & 16 \\ \text { Desmaria } & 1 & \text { Phoradendron } & 240 \\ \text { Eubrachion } & 2 & \text { Phthirusa } & 7 \\ \text { Gaiadendron } & 2 & \text { Psittacanthus } & 118 \\ \text { Lepidoceras } & 2 & \text { Pusillanthus } & 1 \\ \text { Ligaria } & 2 & \text { Struthanthus } & 45 \\ \text { Maracanthus } & 3 & \text { Tripodanthus } & 3 \\ \text { Misodendrum } & 8 & \text { Tristerix } & 13\end{array}$

Total number of accepted neotropical genera: 26 ; number of species: c. 720.

N.B. Viscum album is established in the Santa Rosa, California, area, but is not here taken into account (Scharpf \& Hawksworth 1976).

Note. It has frequently been stated that Loranthaceae consists primarily of large-flowered, ornithophilous species. This is emphatically not true in the New World, where this group has about 132 species, the small-flowered assemblage 170 species (both counts exclude Gaiadendron, Notanthera and Tripodanthus).

\section{KEY TO THE NEW WORLD GENERA OF MISTLETOES}

N.B. It should be noted that the recent classification proposed by Nickrent et al. (2010) places Eremolepidaceae as a separate clade in Santalaceae. Wherever placed, it remains a heterogeneous group, morphologically as well as palynologically and karyologically, with a disjointed geographic distribution.

1. Fruit an achene bearing long, hairy filaments (staminodia) alternating with perianth members, these fused adaxially with the ovary; $\mathrm{S}$ of $33^{\circ} \mathrm{S}$ and $36^{\circ} 30^{\prime} \mathrm{S}$ in Chile and Argentina, respectively .................. Misodendrum

1. Fruit fleshy, seed surrounded by viscin or other slimy cells; stamens or staminodia, where present, positioned adaxially to perianth members (rarely perianth members lacking in male flowers); perianth members not adaxially fused with ovary (female or bisexual flowers); $\mathrm{N}$ of $45^{\circ} \mathrm{S}$ or $40^{\circ} \mathrm{S}$ in Chile \& Argentina, respectively, except Desmaria, Notanthera and Lepidoceras.......................... 2 
2. Ovary crowned with calyculus in at least the female flower; flowers $2 \mathrm{~mm}$ to $30 \mathrm{~cm}$ long, at least the longer ones brightly coloured, including white (Loranthaceae) . . . . . . . 3

2. Calyculus lacking; flowers $3 \mathrm{~mm}$ or less long, greenish or greenish yellow (Eremolepidaceae and Viscaceae) . . 21

3. Epicortical roots on host branches generating leafy shoots; endemic to southern Chile. . . . . . . . . . . . 4

3. Epicortical roots not, or only very rarely, generating leafy shoots, or epicortical roots absent, plants sometimes (Gaiadendron) terrestrial shrubs; not present in Chile except

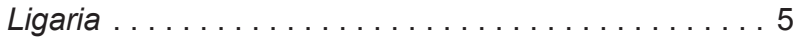

4. Petals bright yellow, nearly $40 \mathrm{~cm}$ long, turning orange in age; short-shoots present, bearing the flowers at the tip; deciduous ................. Desmaria

4. Petals white and pink, to $12 \mathrm{~mm}$ long; short-shoots lacking; plants evergreen ............... Notanthera

5. Petals mostly $>12 \mathrm{~mm}$ long, mostly brightly coloured, including yellow or white . . . . . . . . . 16

5. Petals $<12 \mathrm{~mm}$ long, often greenish white or reddish, not bright yellow ................. 6

6. Flowers sessile in leaf axils, tetramerous; inflorescences lacking . . . . . . . . . . . . . Phthirusa

6. Flowers in axillary and/or in terminal inflorescences; 4-6 petals. . . . . . . . . . . . . . 7

7. Inflorescences mostly determinate, subtended by chartaceous, partly caducous leaf scales ....... Peristethium

7. Inflorescences determinate or indeterminate, lacking basal caducous leaf scales . . . . . . . . . . . 8

8. Inflorescences monadic only . . . . . . . . . . 9

8. Inflorescences triadic or dyadic only (1 or 2 exceptions, Mexico \& Bolivia) . . . . . . . . . . . . . . . . . . . . 14

9. Monads ebracteolate; inflorescences mostly determinate . . . . . . . . . . . . . . . . . . . . . Cladocolea

9. Monads bracteolate, the bracteoles separate or fused with the bract; inflorescence mostly indeterminate . . . . . 10

10. Bracteoles and bracts fused into a cupule; monads pedicellate or sessile . . . . . . . . . . . . . . 11

10. Bracteoles free, small; flowers sessile . . . . . . . 12

11. Staminodia and fertile stamens alternating; anthers basifixed or nearly so; Caribbean only..... . Dendropemon

11. All stamens fertile; anthers dorsifixed, versatile; Chiriquí only . . . . . . . . . . . . . . . . . . Panamanthus

12. Bracteoles narrow, strap-like; pollen with 3 circular depressions on each face; leaf mesophyll with stellate fiber bundles ................... Oryctanthus

12. Bracteoles naviculate, not strap-like, or minute; pollen lacking circular depressions; leaf mesophyll lacking stellate fiber bundles

13. Bracteoles naviculate, prominent; stamens with filaments and evident connectival prominence; Northern Venezuela, Colombia and Costa Rica (Osa Peninsula) Maracanthus

13. Bracteoles extremely small, neither naviculate nor straplike; anthers sessile, minute; Eastern Brazil (one species in Guyana) . . . . . . . . . . . . . . . . . . . . . . Oryctina

14. Inflorescence a capitulum with 2 (4) triads; flowers tetramerous, usually bisexual; tomentose when young; epicortical roots present or not . . . . . . . . . . . Pusillanthus

14. Inflorescence racemic or spike-like, not a capitulum; surfaces glabrous or partly furfuraceous (tomentose in one Bolivian species of Struthanthus); epicortical roots mostly present

15. Anthers basifixed or nearly so, filaments often stout or laterally excavated; flowers bisexual or plants dioecious Passovia
15. Anthers elongate, versatile, filaments slender (very rarely absent); plants dioecious. . . . . . . . . . Struthanthus

16. Inflorescence bearing bracteated monads, or inflorescences absent . . . . . . . . . . . . . . 20 20

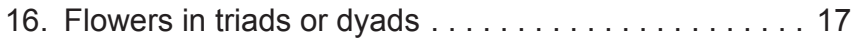

17. Floral bracts and bracteoles foliaceous; primary haustorium lacking; shrubs or small trees, terrestrial or on tree branches ... . . . . . . . . . . . . . . . Gaiadendron

17. Floral bracts and bracteoles not foliaceous (except for the bracts of some Tristerix); primary haustorium present; branch-parasitic on shrubs or trees . . . . . . . . 18

18. Seeds with endosperm; epicortical roots from base of plants and/or from the stem (not known for T. belmirensis Roldán \& Kuijt); inflorescence triadic . . . . . . . . . Tripodanthus

18. Seeds lacking endosperm; epicortical roots mostly lacking; inflorescence triadic or dyadic . . . . . . . . . . 19

19. Anthers needle-like, as thin as the filament, basifixed, with acicular tip; inflorescence dyadic; flowers mostly pendent; higher Andes . . . . . . . . . . . . . . . Aetanthus

19. Anthers not needle-like, thicker than the filament, mostly dorsifixed, lacking acicular tip (exception: $P$. hamulifer Kuijt); inflorescence triadic or dyadic, flowers pendent or not; lower and middle elevations, NW Mexico to Bolivia and Argentina ............... Psittacanthus

20. Inflorescence a raceme; cotyledons cryptocotylar, fused apically; leaves with apical sclerotic nail only in $T$. chodatianus (Patsch.) Kuijt . . . . . . . . . . . . . . Tristerix

20. Inflorescence lacking, flowers individually attached, axillary in position, pedicellate; cotyledons distinct, eventually spreading; leaves with apical sclerotic nail except in L. teretiflora Kuijt . . . . . . . . . . . . . . Ligaria

21. Plants with decussate phyllotaxy throughout $\ldots \ldots 23$

21. Adult plants with alternate phyllotaxy ......... 22

22. Leaves of adult plants squamate and/or peltate; juvenile plants with decussate phyllotaxy; epicortical roots lacking; usually on Myrtaceae . . . . . . . . . . . . . . Eubrachion

22. Plants with expanded foliage, leaves mostly petiolate; both juvenile and adult plants with alternate phyllotaxy; epicortical roots present at least in some species; hosts various Antidaphne

23. Male flowers pedicellate, the inflorescence a raceme; stamens free, filaments present although short; fruit shortpedicellate; Central Andean Peru and Chile S of $35^{\circ} \mathrm{S}$. .

Lepidoceras

23. Male flowers sessile, rarely in 1-flowered units, not in a raceme; anther sessile on perianth member; fruit mostly sessile; $\mathrm{N}$ of $35^{\circ} \mathrm{S}$

24. Plants squamate, dioecious; flowers 1 per axil, sometimes whorled, not sunken in the stem; fruits explosive (exception: A. verticilliflorum Engelm.); female flower with 2 minute perianth members; on Pinaceae only, Canada to Mesoamerica, including Hispaniola . . . . . . . . . Arceuthobium

24. Plants squamate or foliaceous, dioecious or monoecious; inflorescence squamate, spike-like, flowers partly sunken in its axis, 1-many above each axil, in various serial patterns; fruits not explosive; female flowers with 3-4 perianth members; USA to Bolivia and Paraguay-Uruguay, including the Caribbean . . . . . . . . . . . . . . . . 25

25. Anthers unilocular; flowers uni-, (bi-) or triseriate, sometimes with 1 flower per bract; Veracruz to Brazil and Bolivia ................... Dendrophthora

25. Anthers bilocular; flowers bi- or triseriate (sometimes uniseriate, or with 1 flower above each bract); USA to Bolivia and Argentina .............. Phoradendron 


\section{REFERENCES}

Agard JG. 1858. Theoria systematis plantarum ... C.W.K. Gleerup, Lund. APG III (Angiosperm Phylogeny Group). 2009. An update of the Angiosperm Phylogeny Group classification for the orders and families of flowering plants: APG III. Botanical Journal of the Linnean Society 161: 105-121.

Ashworth VETM. 2000a. Phylogenetic relationships in Phoradendreae (Viscaceae) inferred from three regions of the nuclear ribosomal cistron. I. Major lineages and paraphyly of Phoradendron. Systematic Botany 25: 349-370.

Ashworth VETM. 2000b. Phylogenetic relationships in Phoradendreae (Viscaceae) inferred from three regions of the nuclear ribosomal cistron. II. The North American species of Phoradendron. Aliso 19: 41-53.

Barlow BA. 1997. Loranthaceae \& Viscaceae. Flora Malesiana, Ser. I, 13: 209-401, 403-442.

Barlow BA, Wiens D. 1973. The classification of the generic segregates of Phrygilanthus (= Notanthera) of the Loranthaceae. Brittonia 25: 26-39.

Bentham G. 1880. Loranthaceae \& Santalaceae. In: Bentham G, Hooker JD, Genera Plantarum, London.

De Candolle AP. 1830. Mémoire sur les Loranthacées. Collection de Mémoires 6: 12.

Don G. 1834. A general history of dichlamydeous plants 3: 428.

Eichler AW. 1868. Loranthaceae. In: Martius KFP (ed), Flora Brasiliensis 5, 2: 1-136.

Engler A. 1889. Loranthaceae. In: Engler A, Krause K (eds), Die natürlichen Pflanzenfamilien, ed. 1, III, Abt. 1, 156-198. Engelmann, Leipzig.

Engler A. 1897. Loranthaceae. In: Engler A, Prantl K (eds), Die natürlichen Pflanzenfamilien, Nachträge zu III.1: 124-141.

Engler A, Krause K. 1935. Loranthaceae. In: Engler A, Krause K (eds), Die natürlichen Pflanzenfamilien, ed. 2, 16b: 98-203.

Feuillée LÉ. 1714. Journal des observations ... 2: 760. Paris.

Hawksworth FG, Wiens D. 1996. Dwarf mistletoes: biology, pathology, and systematic. United States Department of Agriculture, Forest Service, Agricultural Handbook 709.

Hoffmann GF. 1808. Hortus Mosquensis. Moscow.

Hooker JD. 1846. Flora Antarctica 2: 291, 293.

Karsten H. 1846. Bemerkungen des Hrn. Dr. H. Karsten. Botanische Zeitung (Berlin) 4: 105-112.

Kuijt J. 1961. A revision of Dendrophthora (Loranthaceae). Wentia 6: 1-145.

Kuijt J. 1975. The genus Cladocolea (Loranthaceae). Journal of the Arnold Arboretum 56: 265-335.

Kuijt J. 1976. Maracanthus, a new genus of Loranthaceae. Brittonia 28: 231-238.

Kuijt J. 1980. Miscellaneous mistletoe notes, 1-9. Brittonia 32: 518-529.

Kuijt J. 1983. Status of the genera Aetanthus and Psathyranthus (Loranthaceae). Candollea 38: 661-672.

Kuijt J. 1988a. Monograph of the Eremolepidaceae. Systematic Botany Monographs 18: 1-60.
Kuijt J. 1988b. Revision of Tristerix (Loranthaceae). Systematic Botany Monographs 19: 1-61.

Kuijt J. 1991. Panamanthus, a new monotypic genus of Loranthaceae. Annals of the Missouri Botanical Garden 78: 172-176.

Kuijt J. 2003. Monograph of Phoradendron (Viscaceae). Systematic Botany Monographs 66: 1-643.

Kuijt J. 2008. Pusillanthus (Loranthaceae), a new monotypic genus from Venezuela. Novon 18: 370-373.

Kuijt J. 2009. Monograph of Psittacanthus (Loranthaceae). Systematic Botany Monographs 86: 1-361.

Kuijt J. 2011. Pulling the skeleton out of the cupboard; resurrection of Phthirusa sensu Martius and consequent revival of Passovia Karsten (Loranthaceae). Plant Diversity and Evolution 129: 159-211.

Kuijt J. 2012. Reinstatement and expansion of the genus Peristethium (Loranthaceae). Annals of the Missouri Botanical Garden 98: 542-547.

Linnaeus C. 1753. Species Plantarum, ed. 1.

Marschall von Bieberstein FA. 1819. Flora Taurico-Caucasica ... 3 (4, Suppl.): 629. Charkov.

Martius KFP. 1830. Einige Bemerkungen über Loranthus. Flora 13: 97-112.

Nickrent DL, Malécot V, Vidal-Russell R, Der JP. 2010. A revised classification of Santalales. Taxon 59: 538-558.

Nuttall T. 1848. Descriptions of plants collected by William Gambel, M.D. in the Rocky Mountains and Upper California. Journal of the Academy of Natural Science, Philadelphia, ser. 2, 1: 185-186.

Orfila EN. 1978. Misodendraceae de La Argentina y Chile. Fundación Elías y Ethel Malamud, Buenos Aires.

Poeppig E, Endlicher S. 1838. Nova genera et species plantarum 2: 70. 1838. Reichenbach HGL. 1841. Der Deutsche Botaniker. Das Herbariumbuch 73. Rizzini CT. 1952. Pars generalis prodromi monographiae Loranthacearum Brasiliae terrarumque finitimarum. Arquivos do Jardim Botânico do Rio de Janeiro 12: 39-126.

Rizzini CT. 1956. Pars specialis prodromi monographiae Loranthacearum Brasiliae terrarumque finitimarum. Rodriguésia 30/31: 87-264.

Scharpf RF, Hawksworth FG. 1976. Luther Burbank introduced European mistletoe into California. Plant Disease Reporter 60: 739-742.

Ule E. 1906-1907. Beiträge zur Flora der Hylaea nach den Sammlungen von Ule's Amazonas-Expedition. Verhandlungen der Botanischen Verein Brandenburg 48: 117-208 (Loranthaceae pp. 152-159).

Van Tieghem P. 1895a. Sur le groupement des espèces en genres dans les Loranthacées a calice dialysépale et anthères oscillanthes ou Struthanthées. Bulletin du Société Botanique de France 42: 161-180.

Van Tieghem P. 1895b. Sur le groupement des espèces en genres dans la tribu des Psittacanthées de la famille des Loranthacées. Bulletin du Société Botanique du France 42: 343-362.

Willdenow CL. 1806. Species Plantarum, ed. 4, 4: 740. 